University of Nebraska - Lincoln

DigitalCommons@University of Nebraska - Lincoln

Faculty Publications from the Harold W. Manter Laboratory of Parasitology

February 1991

\title{
Fixing Coccidian Oocysts Is Not an Adequate Solution to the Problem of Preserving Protozoan Type Material
}

Donald Duszynski

University of New Mexico, eimeria@unm.edu

Scott Lyell Gardner

University of Nebraska - Lincoln, slg@unl.edu

Follow this and additional works at: https://digitalcommons.unl.edu/parasitologyfacpubs

Part of the Parasitology Commons

Duszynski, Donald and Gardner, Scott Lyell, "Fixing Coccidian Oocysts Is Not an Adequate Solution to the Problem of Preserving Protozoan Type Material" (1991). Faculty Publications from the Harold W. Manter Laboratory of Parasitology. 22.

https://digitalcommons.unl.edu/parasitologyfacpubs/22

This Article is brought to you for free and open access by the Parasitology, Harold W. Manter Laboratory of at DigitalCommons@University of Nebraska - Lincoln. It has been accepted for inclusion in Faculty Publications from the Harold W. Manter Laboratory of Parasitology by an authorized administrator of DigitalCommons@University of Nebraska - Lincoln. 


\title{
FIXING COCCIDIAN OOCYSTS IS NOT AN ADEQUATE SOLUTION TO THE PROBLEM OF PRESERVING PROTOZOAN TYPE MATERIAL
}

\author{
Donald W. Duszynski and Scott L. Gardner \\ Department of Biology, The University of New Mexico, Albuquerque, New Mexico 87131
}

\begin{abstract}
Fresh (36 days old) sporulated oocysts of Eimeria nieschulzi were divided into 7 groups. Control oocysts were maintained at $23 \mathrm{C}$ in $2 \%$ aqueous (w/v) $\mathrm{K}_{2} \mathrm{Cr}_{2} \mathrm{O}_{7}$. The 6 experimental groups were mixed with either Bouin's solution, $10 \%$ aqueous $(\mathrm{v} / \mathrm{v})$ buffered formalin, Karnovsky's solution, glutaraldehyde, paraformaldehyde, or $70 \%$ aqueous (v/v) ethanol (EtOH). After 115 days, oocysts from all 7 groups were examined under oil immersion to determine the effect of fixation on their structural integrity. The parameters examined were lengths and widths of oocysts and sporocysts, percent sporulation $(\% \mathrm{~S})$, and percent crenation $(\% \mathrm{C})$ of oocysts and sporocysts. The highest destruction $(\% \mathrm{~S}$ and $\% \mathrm{C})$ occurred in oocysts exposed to glutaraldehyde and Karnovsky's fixatives where $100 \%$ of both oocysts and sporocysts crenated and only $8 \%$ and $48 \%$, respectively, remained sporulated. Of the oocysts in paraformaldehyde, $93 \%$ remained sporulated, but $95 \%$ of these oocysts and $100 \%$ of the sporocysts crenated. In Bouin's solution, $75 \%$ of the oocysts were intact structurally, but of these, only $60 \%$ were still sporulated with $70 \%$ of their sporocysts crenated. Oocysts preserved in $70 \% \mathrm{EtOH}$ were $80 \%$ intact and $70 \%$ remained sporulated, but nearly $60 \%$ of their sporocysts collapsed even though the oocyst walls were intact. Oocysts preserved in $10 \%$ buffered formalin maintained structural integrity but had lower numbers of sporulated oocysts $(84 \%)$ and greater numbers of crenated oocysts (18\%) than control oocysts maintained in the dichromate solution ( $95 \%$ and $0 \%$, respectively).
\end{abstract}

Bandoni and Duszynski (1988) proposed 2 methods, preserving oocysts in resin (see Marchiondo and Duszynski, 1978, 1988) or standardization of a photographic procedure (phototypes), by which type specimens of coccidian oocysts could be submitted to, and maintained in, accredited national museums. Unfortunately, some authors continue to describe new coccidian species without preserving any kind of type specimen(s), whereas others have sent sporulated oocysts to accredited musuems by storing them in $70 \%$ ethanol (e.g., McAllister et al., 1988). The latter may be an easy and acceptable method to preserve oocysts, but no one, to our knowledge, has compared the effect of common fixation solutions on sporulated oocysts over time or analyzed the results of such an experiment in a comparative way. In this paper, we evaluate the utility of 6 common laboratory fixatives for preserving sporulated oocysts for museum deposition.

\section{MATERIALS AND METHODS}

Approximately 5,000 sporulated oocysts ( 3.5 mo old) of Eimeria nieschulzi Dieben, 1924, were inoculated per os into 2 outbred laboratory rats, Rattus norvegicus (Berkenhout). The oocysts that rats discharged were collected on days 8-10 postinoculation (PI), pooled, separated from fecal debris by filtering through brass screens, sporulated in petri dishes for 7 days at $23 \mathrm{C}$, and then stored at $4 \mathrm{C}$ in $2 \%$ aqueous ( $\mathrm{w} / \mathrm{v})$ potassium

Received 18 April 1990; revised 7 June 1990; accepted 14 June 1990. dichromate $\left(\mathrm{K}_{2} \mathrm{Cr}_{2} \mathrm{O}_{7}\right)$ solution as described before (Duszynski, 1972). When oocysts were 36 days old they were washed and concentrated by petri dish flotation (Hammond et al., 1968) and divided into 7 groups of several million sporulated oocysts each. Control oocysts were maintained at room temperature $(23 \mathrm{C})$ in the dichromate solution. The other 6 groups of oocysts were mixed 1:9, each with a different fixative, such that the final solution consisted of $10 \%$ clean oocyst-dichromate solution and $90 \%$ fixative. The fixatives used were Bouin's (Humason, 1979), 10\% aqueous (v/v) buffered formalin (Humason, 1979), Karnovsky's (Karnovsky, 1965), 2\% glutaraldehyde in cacodylate buffer (Humason, 1979), 4\% (w/v) paraformaldehyde (Ubelaker et al., 1988), and 70\% aqueous (v/v) ethanol $(\mathrm{EtOH})$. Oocysts were left in fixative for 115 days. Then, a drop of oocyst-fixative solution was placed on a glass slide and covered with a coverglass that had been ringed with petrolatum to prevent evaporation. All oocysts were examined under oil immersion with a Zeiss Universal Photomicroscope equipped with both Neofluar and Nomarsky interference contrast $100 \times$ objectives. The first 100 oocysts seen were scored for percent sporulation (\%S) and percentage of the oocysts in which the oocyst wall and/or sporocyst walls were markedly crenated $(\% \mathrm{C})$. Four measurements (lengths and widths of oocyst and sporocysts, $n=25$ each) were then taken using a video analysis system (JAVA tm) and univariate and multivariate statistics were generated using Statistical Analysis Systems (Anonymous, 1985) and the Biostat II statistical package (Pimentel and Smith, 1986). For all comparisons, statistical probabilities were set a priori at $P \leq 0.05$.

\section{RESULTS}

Univariate summary statistics were calculated for each treatment group to examine the extent 
TABLE I. Mean oocyst and sporocyst lengths and widths (in $\mu \mathrm{m}$ ), ranges, standard deviations (SD), and coefficients of variation $(\mathrm{CV})$ for groups of fixed and unfixed (control) oocysts of Eimeria nieschulzi. For each group $\mathrm{n}=25$.

\begin{tabular}{|c|c|c|c|c|c|c|c|}
\hline & \multirow{2}{*}{$\begin{array}{l}\text { Unfixed } \\
\text { oocysts } \\
\text { (control) }\end{array}$} & \multicolumn{6}{|c|}{ Fixatives used } \\
\hline & & Bouin's & Formalin & Karnovsky's & $\begin{array}{c}\text { Glutaral- } \\
\text { dehyde }\end{array}$ & $\begin{array}{c}\text { Paraformal- } \\
\text { dehyde }\end{array}$ & $70 \% \mathrm{EtOH}$ \\
\hline \multicolumn{8}{|l|}{ Oocyst } \\
\hline Length & 20.1 & 20.5 & 20.1 & 19.8 & 20.1 & 19.5 & 21.1 \\
\hline Range & $18-23$ & $16-23$ & $16-25$ & $15-24$ & $17-24$ & $16-22$ & $18-24$ \\
\hline $\mathrm{SD}$ & 1.4 & 1.6 & 2.0 & 2.2 & 2.2 & 2.0 & 1.7 \\
\hline $\mathrm{CV}$ & 6.7 & 7.8 & 10.1 & 11.2 & 10.9 & 10.4 & 8.1 \\
\hline Width & 15.8 & 15.9 & 15.7 & 14.8 & 15.4 & 15.1 & 16.6 \\
\hline Range & $14-18$ & $12-17$ & $14-18$ & $12-16$ & $12-18$ & $13-18$ & $14-19$ \\
\hline SD & 1.2 & 1.1 & 0.9 & 1.1 & 1.6 & 1.5 & 1.2 \\
\hline $\mathrm{CV}$ & 7.8 & 7.0 & 5.8 & 7.4 & 10.7 & 9.7 & 7.5 \\
\hline \multicolumn{8}{|l|}{ Sporocyst } \\
\hline Length & 10.9 & 10.5 & 10.7 & 10.3 & 9.9 & 9.9 & 11.0 \\
\hline Range & $10-12$ & $7-13$ & $9-12$ & $7-12$ & $8-12$ & $7-13$ & $10-12$ \\
\hline $\mathrm{SD}$ & 0.7 & 1.6 & 0.8 & 1.0 & 1.3 & 1.6 & 0.6 \\
\hline $\mathrm{CV}$ & 5.9 & 14.9 & 7.7 & 9.9 & 12.7 & 16.6 & 5.2 \\
\hline Width & 7.1 & 6.8 & 6.9 & 6.9 & 6.6 & 7.1 & 7.0 \\
\hline Range & $6-8$ & $5-8$ & $6-9$ & $5-9$ & $4-8$ & $5-11$ & $5-9$ \\
\hline SD & 0.6 & 0.7 & 0.7 & 0.9 & 0.8 & 1.3 & 0.7 \\
\hline $\mathrm{CV}$ & 8.4 & 10.9 & 10.3 & 13.0 & 11.4 & 18.9 & 9.7 \\
\hline
\end{tabular}

of variation around the mean for each of the 4 measurements. Only unfixed oocysts (controls) and those fixed in $70 \%$ EtOH had small variability around the mean whereas the other 5 fixatives caused a large increase in structural variation (Table I). The distortion of the oocysts and sporocysts varied with the fixative used (cf. Figs. 13 vs. 4-16), with the highest destruction of structural integrity (both \%S and \%C) seen in oocysts exposed to Karnovsky's and glutaraldehyde fixation regimes (Table II; Figs. 4-7), with every oocyst in Karnovsky's solution crenated badly (Figs. 4, 5) or deteriorated. All glutaraldehydefixed oocysts were in very poor condition (Figs. $6,7)$ and very few sporozoites could be identified; virtually all internal contents of all sporocysts seemed to have disintegrated in this fixative. The best fixative for preserving \%S over the 115 days was paraformaldehyde, but this advantage was offset by the high percentage of oocysts that crenated in this fixative (Table II; Figs. 8, 9). In addition, this fixative made the oocysts much more refractive under Nomarsky interference microscopy when compared to unfixed oocysts (cf. Figs. 3 and 9). Three fixatives, Bouin's, 70\% $\mathrm{EtOH}$, and $10 \%$ buffered formalin, did an adequate job preserving oocyst structure (Table II), but each also had drawbacks. Sporocysts in Bouin-preserved oocysts seemed to have lost their internal clarity and sharpness (Fig. 10), about $40 \%$ looked misshapen (Fig. 11) or had begun to disintegrate (Fig. 12), and $25 \%$ of their oocysts had crenated. Additionally, in Bouin-fixed oocysts that were sporulated and not crenated, about $70 \%$ of the sporocysts were collapsed. These effects were less severe in $70 \% \mathrm{EtOH}$-preserved oocysts, but in these, nearly $60 \%$ of the sporulated oocysts had sporocysts that were collapsing (Figs. 13, 14) even though the majority of these oocyst walls had maintained their integrity. Oocysts preserved in $10 \%$ buffered formalin looked the best after 115 days in fixative (Fig. 15), but even these had significantly lower numbers of sporulated oocysts over time (Table II) and significantly greater \%C (Fig. 16) when compared to controls maintained in only the $2 \%$ dichromate solution.

Discriminant analysis and Geisser classification were used to determine the extent that spor-

TABLE II. Percent sporulation (\%S) and percent crenation $(\% \mathrm{C})$ of oocysts of Eimeria nieschulzi after storage for 115 days in various fixatives compared to control oocysts stored in $2 \%$ aqueous $(\mathrm{w} / \mathrm{v})$ potassium dichromate $\left(\mathrm{K}_{2} \mathrm{Cr}_{2} \mathrm{O}_{7}\right)$ solution over the same time period. For each group $\mathrm{n}=100$.

\begin{tabular}{lrcc}
\hline \multicolumn{1}{c}{ Fixative } & $\%$ S & \%C oocysts & $\begin{array}{c}\% \mathrm{C} \\
\text { sporocysts }\end{array}$ \\
\hline None: control & 95 & 0 & 0 \\
Bouin's & 60 & 25 & 70 \\
Formalin & 84 & 18 & 0 \\
Glutaraldehyde & 8 & 100 & 100 \\
Karnovsky's & 48 & 100 & 100 \\
Paraformaldehyde & 93 & 95 & 100 \\
70\% EtOH & 70 & 19 & 58 \\
\hline
\end{tabular}



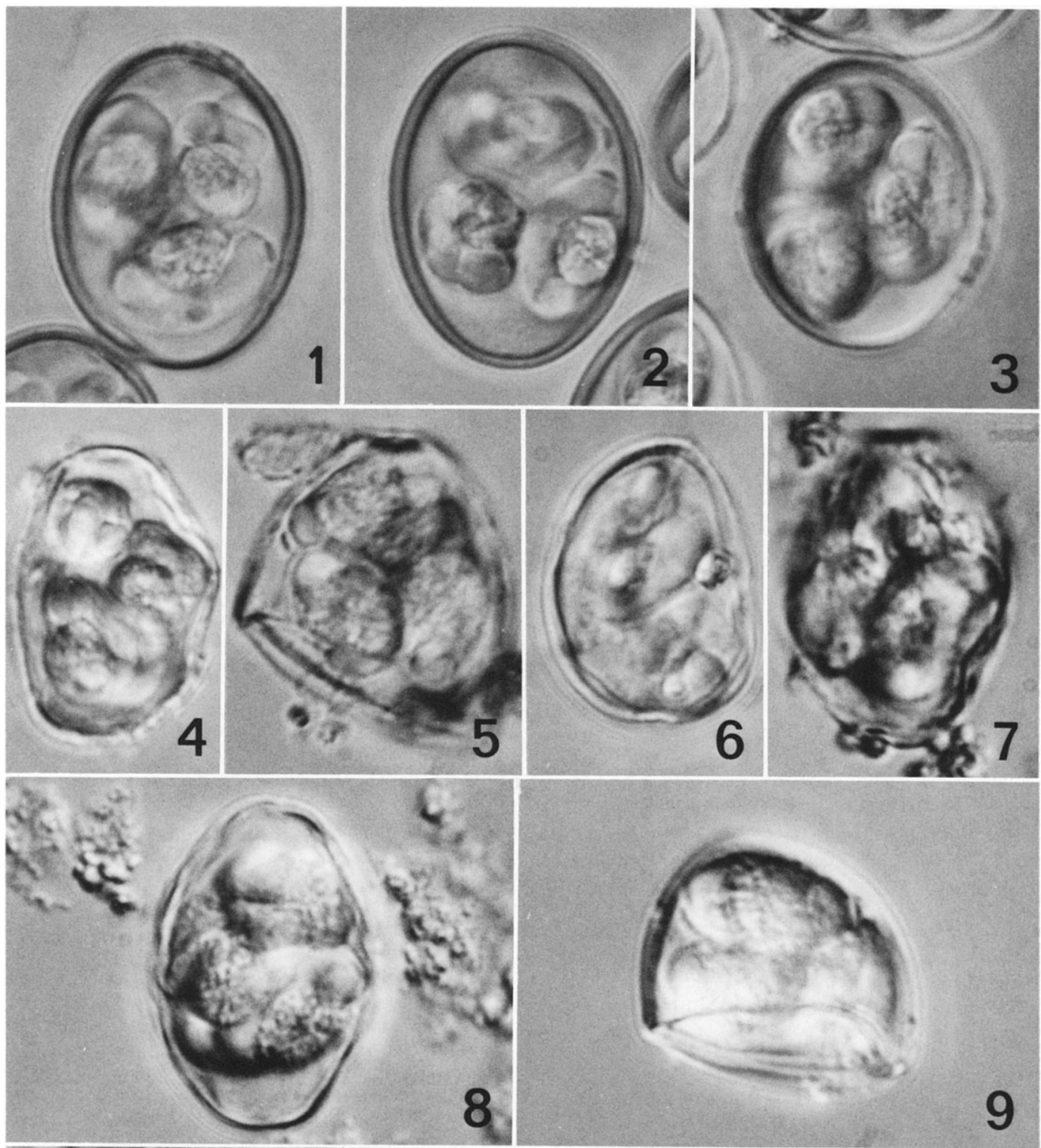

9
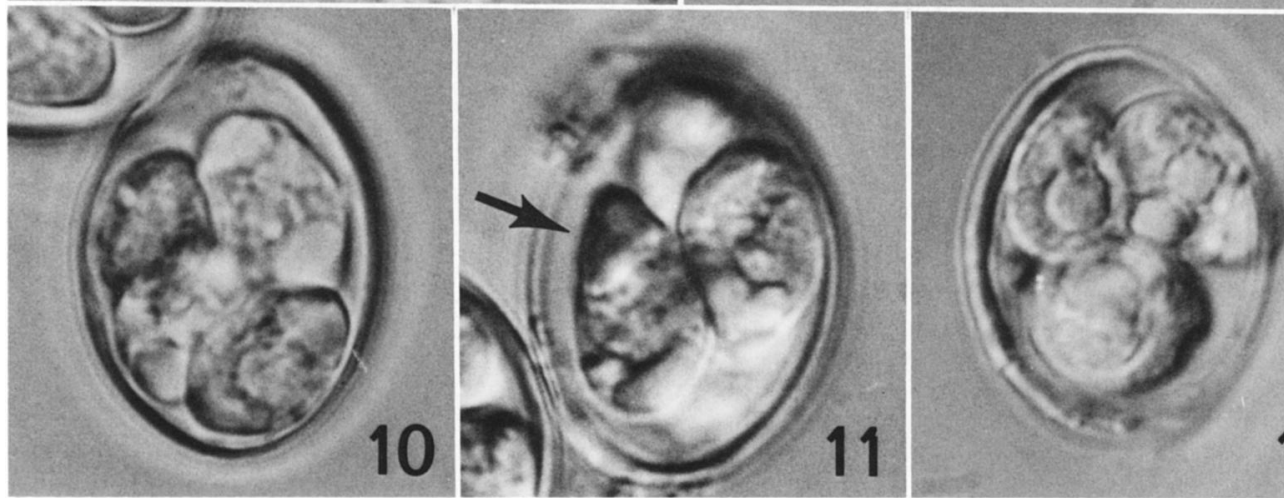

12 


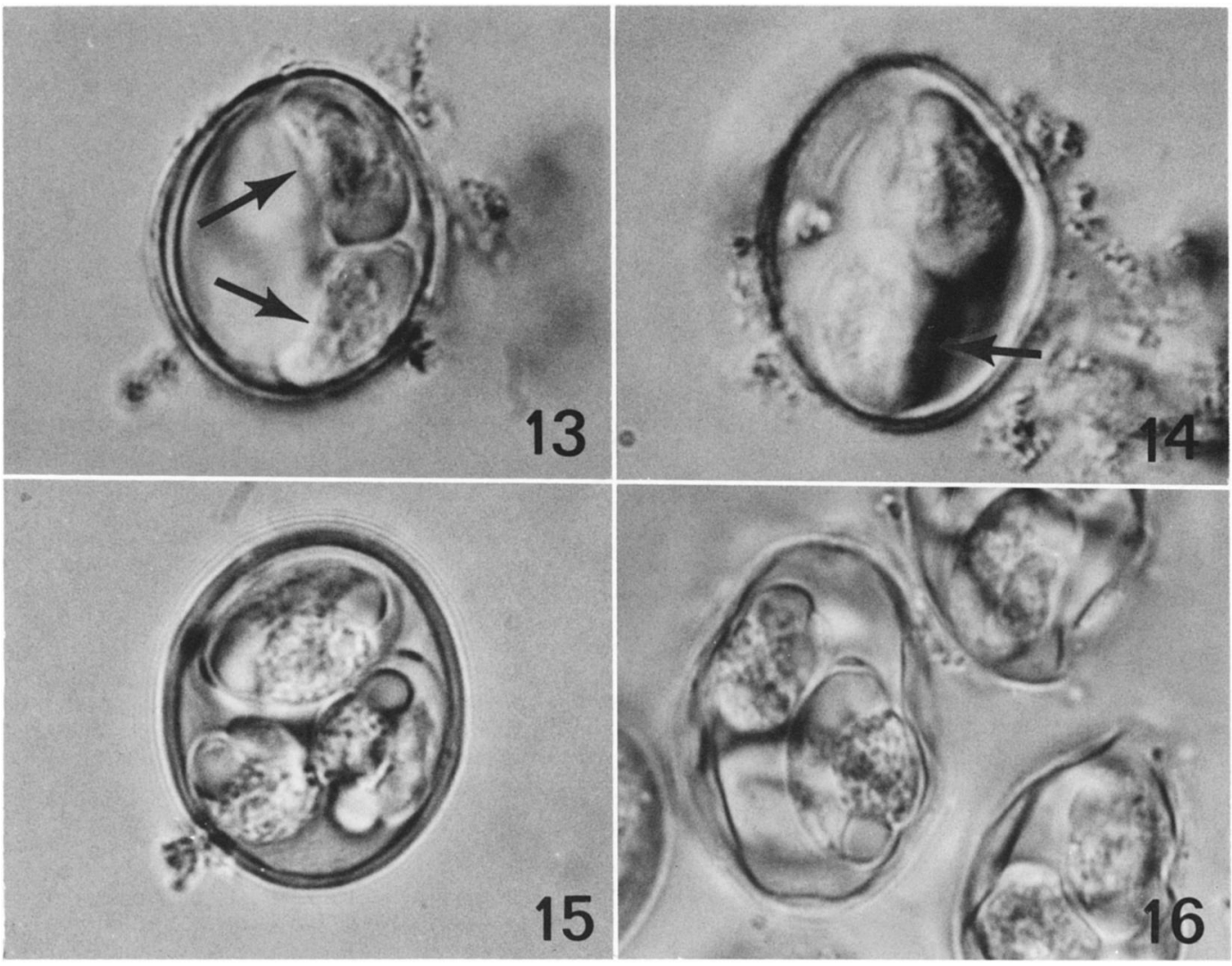

FIGURES 13-16. Photomicrographs of sporulated oocysts of Eimeria nieschulzi subjected to standard laboratory fixatives for 115 days. All oocysts viewed in their fixative, not via sugar flotation. $\times 1,760.13,14$. Oocysts fixed in $70 \%$ EtOH. Note (arrows) how sporocysts are collapsing even though oocyst walls remain intact. 15, 16. Oocysts fixed in $10 \%$ buffered formalin. Note that even though the sporocysts look good, many oocysts are crenated in Figure 16.

ulated oocysts of $E$. nieschulzi, subjected to different fixatives over time, could be separated. Statistical consideration of the 4 measurements (oocyst and sporocyst length and width) simultaneously allowed us to make a multivariate assessment of the degree of morphological change of the oocysts induced by the different fixatives. The scatter plot of discriminant scores (Fig. 17) indicates the increased variability seen in fixed oocysts when these were compared to the vari- ability of oocysts stored in $2 \%$ dichromate solution for the same amount of time.

\section{DISCUSSION}

The data indicate that a variety of common laboratory fixatives destroy the structural integrity of sporulated oocysts. These changes, which are easily monitored by noting changes in $\% \mathrm{~S}$ and $\% \mathrm{C}$ over time, varied from fixative to fixative. At one extreme, $100 \%$ of the oocysts and

FIGURES 1-12. Photomicrographs of sporulated oocysts of Eimeria nieschulzi both unfixed and those subjected to standard laboratory fixatives (see Materials and Methods) for 115 days. All oocysts viewed in their fixative, not via sugar flotation. $\times 1,760$. 1-3. Control oocysts kept in $2 \%$ aqueous $(w / v) \mathrm{K}_{2} \mathrm{Cr}_{2} \mathrm{O}_{7}$. 4, 5. Oocysts fixed in Karnovsky's fixative. 6, 7. Oocysts fixed in $2 \%$ glutaraldehyde. 8, 9. Oocysts fixed in $4 \%$ paraformaldehyde. Compare to Figure 3 and note how this fixative changed the refractive index of the stored oocysts. 10-12. Oocysts stored in Bouin's fixative. Note in Figure 10 how internal structures have lost their clarity and in Figure 11 (arrow) how the sporocyst seems misshapen. 


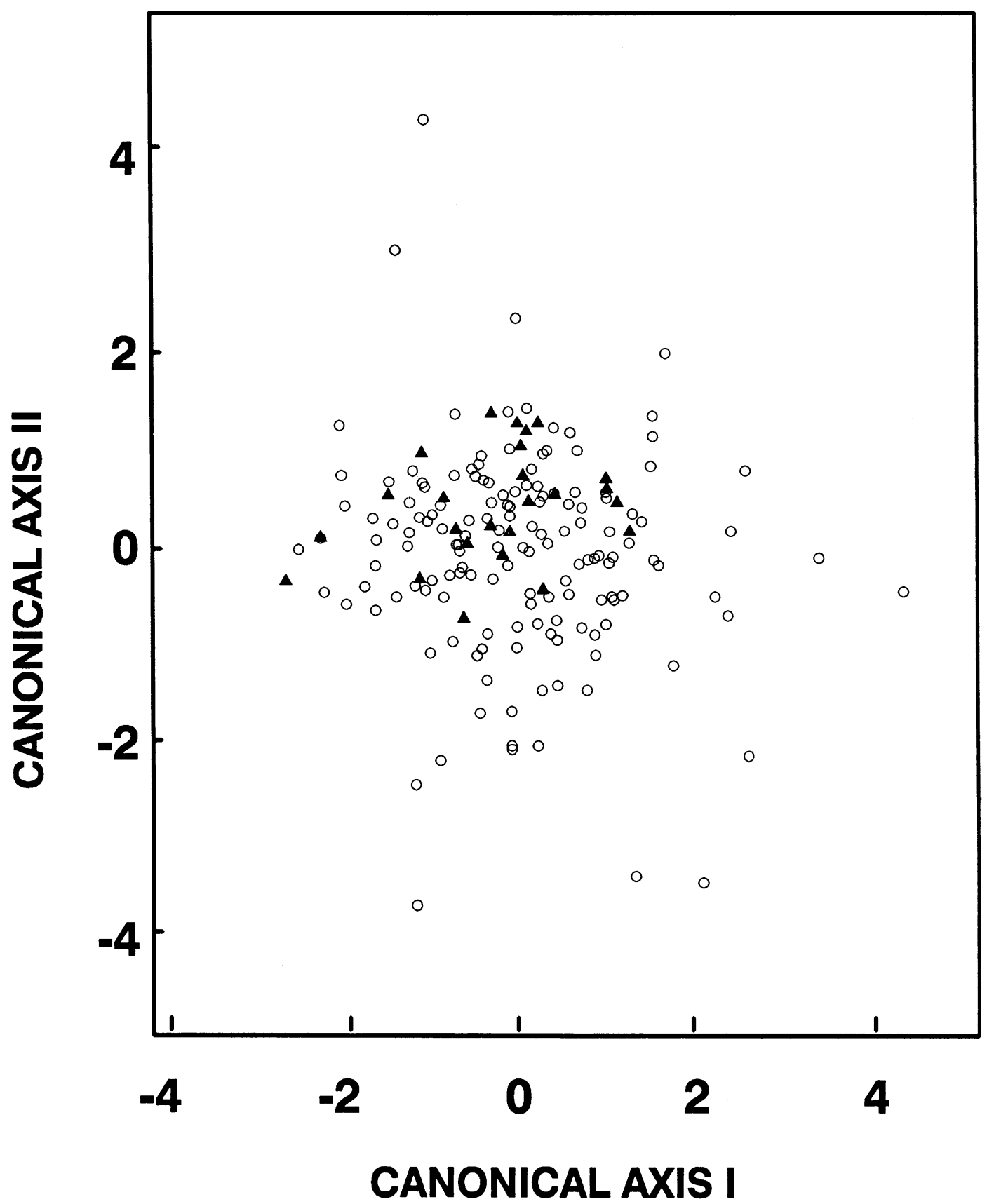

FIGURE 17. Scatter plot of discriminant scores showing the increased variability in lengths and widths of oocysts and sporocysts when seen in fixed oocysts (O) vs. oocysts stored in $2 \%$ dichromate solution for the same amount of time (A).

sporocysts were crenated badly and less than half of the oocysts remained sporulated when sporulated oocysts were exposed to glutaraldehyde or Karnovsky's fixatives for 115 days. At the other extreme, about $85 \%$ of the oocysts in $10 \%$ buff- ered formalin maintained their structural integrity for at least the 115 days used in this experiment, but it is unknown whether this figure will remain constant over additional time in fixative. We conclude that the fixation of oocysts is, by 
itself, an unsuitable procedure for preserving sporulated oocysts over time, at least in regard to the parameters of our experimental design. Thus, oocysts that represent new species either should be permanently fixed in resin (Marchiondo and Duszynski, 1978, 1988) or a phototype tradition should be adopted as suggested by Bandoni and Duszynski (1988).

\section{ACKNOWLEDGMENTS}

Sincere thanks are due Mr. David Keller for much technical assistance during the course of our experiments.

\section{LITERATURE CITED}

ANONYmous. 1985. SAS user's guide: Statistics, Version 5 ed. SAS Institute, Inc., Cary, North Carolina, $956 \mathrm{p}$.

BANDONI, S. M., AND D. W. DuszYNSKI. 1988. A plea for improved presentation of type material for coccidia. Journal of Parasitology 74: 519-523.

DuszYNSKI, D. W. 1972. Host and parasite interactions during single and concurrent infections with Eimeria nieschulz $i$ and $E$. separata in the rat. Journal of Protozoology 19: 82-88.

Hammond, D. M., B. Сhobotar, AND J. V. ERnst. 1968. Cytological observations on sporozoites of Eimeria bovis and E. auburnensis and an Eimeria species from the ord kangaroo rat. Journal of Parasitology 54: 550-558.

Humason, G. L. 1979. Animal tissue techniques, 4th ed. W. H. Freeman and Co., San Francisco, $661 \mathrm{p}$.

KARNOVSKY, M. J. 1965. A formaldehyde-glutaraldehyde fixative of high osmolality for use in electron microscopy. Journal of Cell Biology 27: 137A.

MARChIONDO, A. M., AND D. W. DusZYNSKI. 1978. Permanent light microscopy slides of Eimeria nieschulzi oocysts. Journal of Parasitology 64: 163164.

, AND - 1988. On the status of Eimeria nieschulzi oocysts embedded in resin eleven years ago: A permanent method for preserving coccidian oocysts. Journal of Parasitology 74: 740-742.

McAllister, C. T., S. J. Upton, AND P. S. Freed. 1988. Eimeria lineri sp. n. (Apicomplexa: Eimeriidae) from the Mediterranean gecko, Hemidactylus turcicus (Sauria: Gekkonidae), in Louisiana and Texas. Proceedings of the Helminthological Society of Washington 55: 256259.

Pimentel, R. A., AND J. D. Smith. 1986. Biostat II. A multivariate statistical toolbox. Sigma Soft, Placentia, California, 212 p.

Ubelaker, J. E., V. F. Allison, J. E. Ricker, AND D. W. DUSZYNSKI. 1988. The ultrastructure of cement glands in a rhabdocoel turbellarian Syndisyrinx sp. Parasitology Research 74: 216-220. 